\title{
Young people and the post-recession labour market in the context of Europe 2020
}

Heejung Chung ${ }^{1}$ University of Kent

Sonja Bekker Tilburg University

Hester Houwing UVW: Dutch Unemployment Insurance

\section{Summary}

This article examines how the recent global recession, together with the general flexibilization of labour markets, is affecting young people. We examine different forms of social exclusion, including unemployment, temporary employment contracts and periods of inactivity, as well as the subjective insecurity arising from such labour market exclusion. We also examine what Member States have done to address this issue, especially as part of their response to the crisis. At both EU (through the Europe 2020 strategy) and national levels specific policy measures exist that target young people in the labour market, but these are mostly supplydriven. Thus, they do not take into account the true problems young people are facing, including problems finding first-time employment and bad-quality jobs with little prospect of moving up the employment ladder. In conclusion, a new generation with higher exposure to systematic labour market risks than previous generations is being left to fend for itself with little appropriate state support.

\section{Keywords}

Young workers, economic recession, labour market insecurity, policy responses, EU2020

\footnotetext{
${ }^{1}$ Author for correspondence: Heejung Chung, Cornwallis NorthEast, SSPSSR, Faculty of Social Sciences, University of Kent, Canterbury Kent, CT2 7NF, United Kingdom. Email: h.chung@kent.ac.uk
} 


\section{Introduction}

The recent economic recession has had a great impact on European labour markets. In particular we are seeing specific groups being affected more severely than others. One group particularly hard hit is that of younger workers. For example, in the second quarter of 2011, some 21 percent of young people in the 15-24 age range were unemployed (see next section), almost three times higher than the corresponding figure for prime-age workers. Moreover forecasts predict a further deterioration in the labour market in the coming years, with young workers suffering the most. This is all leading to young people becoming and feeling marginalized, as witnessed by the wave of social unrest with youth riots and mass demonstrations in countries such as Spain, the UK and Greece. When we take the various effects of unemployment and income and employment insecurity into account, the recession has the potential to have a devastating impact on the future of these young people, not only in terms of their future employment status but also on such aspects as family formation and general well-being (Scarpetta et al., 2010). Several organizations have begun focusing on ways of tackling youth unemployment and marginalization, including the European Commission whose Employment in Europe 2010 Report addresses the problems of labour market segmentation with regard to young workers. One of the key Europe 2020 initiatives 'Youth on the Move' - focuses on youth employment, and the Commission has recently launched its Youth Opportunities Initiative via which European Social Funds are allocated to support vocational training, apprenticeships, business start-ups and the like (European Commission, 2010a). Member States have also addressed these issues in their policy agendas. However, the policy focus of both the Commission and Member States lies in increasing participation in the labour market and education and supporting school-to-work transitions, while not sufficiently addressing the problems associated with the increase in systematic insecurity and the segmentation of the younger population. There is also a problem of defining young workers. Most policies focus on people in their early 20s, disregarding the problems of young people aged 25-35, i.e. those struggling to stand on their own two feet, with a job, home and family. Lastly, with unions not sufficiently addressing the issues of younger workers, this is set to have dire consequences on sustaining trade union membership.

This article aims to examine the problems surrounding the labour market and social exclusion with regard to young workers, and to analyse both Member States' and EU responses. It starts by examining the current state of affairs in terms of youth exclusion, 
looking at the impact of the recent global recession, and the general flexibilization of the labour market in Europe and the impact thereof on young people. We examine different forms of social exclusion, including unemployment, temporary employment and periods of inactivity as well as the subjective insecurity arising from such labour market exclusion. We move on to explore what Member States have done in terms of adapting policy to address this issue as a crisis response, focusing on three EU Member States, Spain, the Netherlands and Sweden, three countries with differing labour market and welfare state regime typologies. We end by taking a critical look at Europe 2020 and how this attempts to tackle the problem. The article concludes by listing certain additional measures deemed necessary to tackle this issue, including changes in the structure of social policy and labour legislation as well as union policies.

\section{Transnational trends in the status of young people in the labour market}

\section{Defining young workers}

Most studies examining youth employment issues define youth or young people as being in the 15(16)-24(23) age range (European Foundation for the Improvement of Living and Working Conditions, 2011; Holzer, 1987; Ihlanfeldt and Sjoquist, 1990; ILO, 2011; Scarpetta et al., 2010). This definition is linked to the transition young people go through between school and work, with 15 being the (earliest) age at which individuals with lower secondary education leave school and 24 being the age where most individuals with tertiary education leave college or university.

In this article, we distinguish between two types of young workers: 1) those entering the labour market from school or university education, generally in the 15-24 age range, and 2) those who have already entered the labour market but - in most cases - have not (yet) found a secure job. We argue that in neglecting the labour market status of 25-34 year olds, policies fail to take into account the fact that this age group is also affected by the increasing flexibilization of the labour market, further postponing their ability to obtain secure jobs. Currently, workers in the 25-34 age range are often out of the focus of policy-makers and as a result do not benefit from policies aimed at improving the position of young workers. How best to define this group in terms of age is a topic for debate, and there are also problems with 
data availability here. Where data are available, we will extend our target group up to 34 year olds, with subdivisions of 15/18-24 and 25-34. We will compare these age groups to primeage workers (35-54), older workers (55-64) and the retired - (65 plus).

\section{Unemployment and NEET}

Two of the main problems young people currently face are entering the labour market and staying in employment. Looking at what happened to the labour market in the wake of the 2008 crisis, we see younger workers more affected than the rest of the population as the former are more sensitive to economic cycles (Scarpetta et al., 2010). As the following figures show, more than 20 percent of young people in the 15-24 age range in Europe and almost half (46.1 percent) of those in Spain were unable to find a first job in the second quarter of 2011.

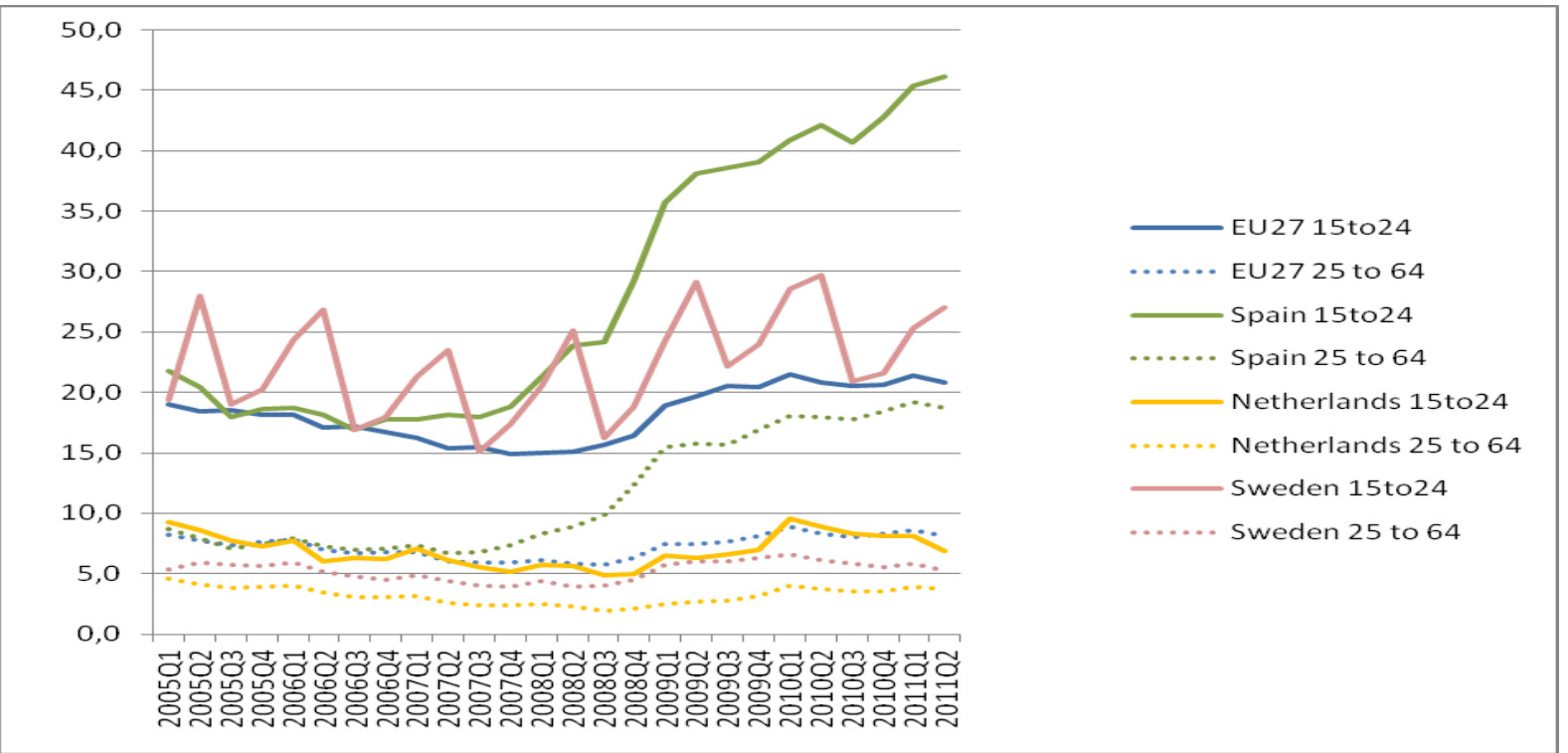

Figure 1. Unemployment rate changes across Europe (2005-2011)

Source: Eurostat.

Whereas in 2004 the overall EU-27 unemployment rate for the 15-24 age range of workers was 2.5 times higher than that of the 35-54 age range, this increased to 2.9 in 2008 and 2009. Though dropping slightly in 2010, this however only reflected the steady rise in the unemployment rate of older workers. In Sweden for instance, younger workers were 5.1 times more likely to be unemployed than prime age workers in the second quarter of 2011, although we also see a strong cyclical pattern of unemployment amongst Swedish young people, most likely reflecting the increase in temporary jobs available during summer holidays. In Spain 
young workers are 2.5 times more likely to be unemployed than older workers, whereas in the Netherlands the corresponding figure is 1.9 .

When using the broader definition of younger workers, we see that the employment disparity between age groups exists not only for young workers (15-24) but also for slightly older workers (25-34) (see Figure 2). In other words, it is not just the 15-24 age range, but also the 25-35 range which is more likely to be unemployed than prime age and older workers. In addition, as with younger workers, this disparity has been steadily increasing, with the rise more pronounced in the wake of the economic crisis. By the third quarter of 2010, workers in the 25-34 age range were 1.5 times more likely to be unemployed than those in the 35-54 range, a 50 percent increase over the previous five years.

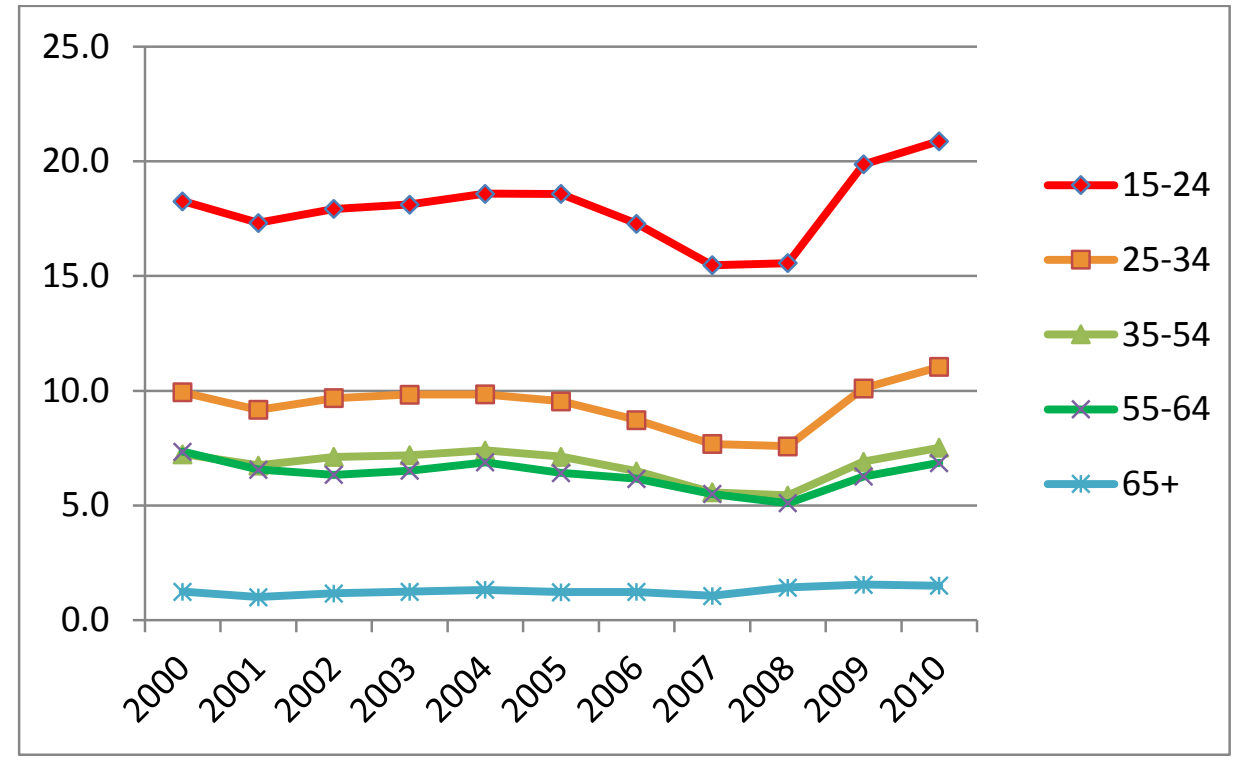

Figure 2. Unemployment rate changes for EU-27 countries: averages by detailed age grouping from 2000 to 2010

Source: Eurostat LFS.

The problem of exclusion can be seen in the percentage of those who are not in employment, education and training - the so-called NEETs. Figure 3 shows the percentage of 15-24 and 25-34 year old NEETs. Here we see that NEET rates had been steadily declining from the beginning of 2000 until the economic crisis, only to dramatically increase from 2008 onwards. Of the three countries in focus, Spain has the highest youth NEET rate, with approximately 18 
percent of 15-24 year olds and 24 percent of 25-34 year olds being NEET. Though youth NEET rates are lower in both Sweden and the Netherlands, this rate is slowly rising in the latter. One interesting point is that the NEET rate for the 25-34 age range is higher than that for the 15-24 range in the EU-27 and the three countries under investigation. This may partly be a result of women with young children (temporarily) leaving the labour market. In addition, the 2010 increase in the NEET rate is much more pronounced for the 25-34 age range. This could be attributable to the lack of vocational education and training (VET) programmes addressing this age group, an issue looked at more closely in the policy section. In other words, although the unemployment rate of 15 to 24 year olds may be higher than that of 25 to 34 year olds, the younger group is more likely to be taking part in some form of VET programme unavailable to those over 25 (more details in Sections 3 and 4).

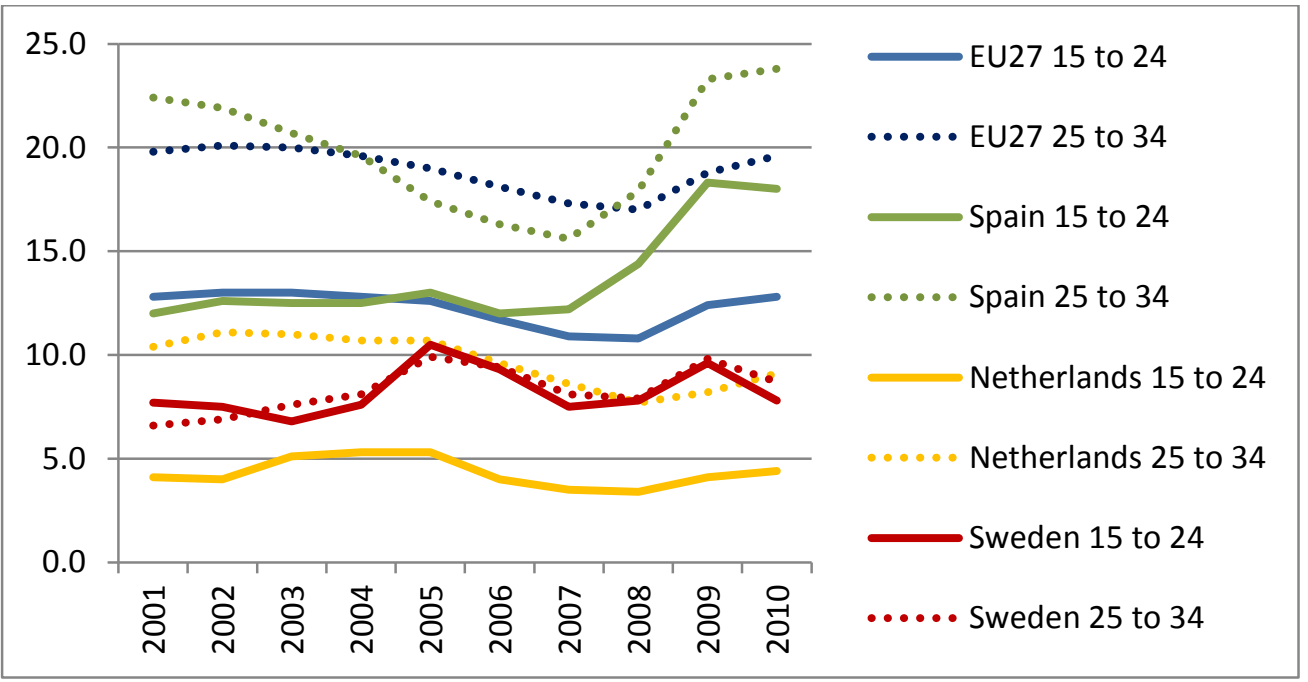

Figure 3. Percentage of population not in employment, education or training

Source: Eurostat.

\section{Insecurity and segmentation within the labour market}

The problems for young workers do not stop once they have entered the labour market or found a job. When employed, it is highly likely that younger workers will have temporary contracts. Young people are finding it increasingly difficult to find long-term employment, 
even during periods of strong economic growth. They frequently rotate between temporary jobs, unemployment and/or periods of inactivity (Scarpetta et al., 2010: 18-19). This likelihood is again much higher than with older workers and we are observing a steady increase in the precariousness of youth jobs (Scarpetta et al., 2010). Within the EU-27, 17.4 percent of all employed workers in the 25-34 age range and 42 percent in the 15-24 age range are on temporary contracts. This is respectively two and five times higher than for the 35-54 age range, and again this gap has been steadily widening since 2004 (Figure 4).

We find a transnational variance between older and younger workers in this disparity of the contract types they hold. In Spain, where generally a larger share of workers in all age groups work on temporary contracts compared to other countries, although the share of younger workers on temporary contracts is high (58.6 percent for the $15-24$, and 32.3 percent for $25-$ 34 age group), the disparity between these two age groups and the group of prime-age workers is not very large. By contrast, in Sweden where temporary contracts are not used as frequently, precariousness predominates in young workers, with 15-24 year olds eight times more likely (57.1 percent) than $35-54$ year olds (7.3 percent) to be on temporary contracts, and the percentage of young workers on temporary contracts comparable to that of Spain. Those aged 25-34 are also three times more likely to be in temporary employment. A similar pattern can be found in the Netherlands, but not to such a large degree.

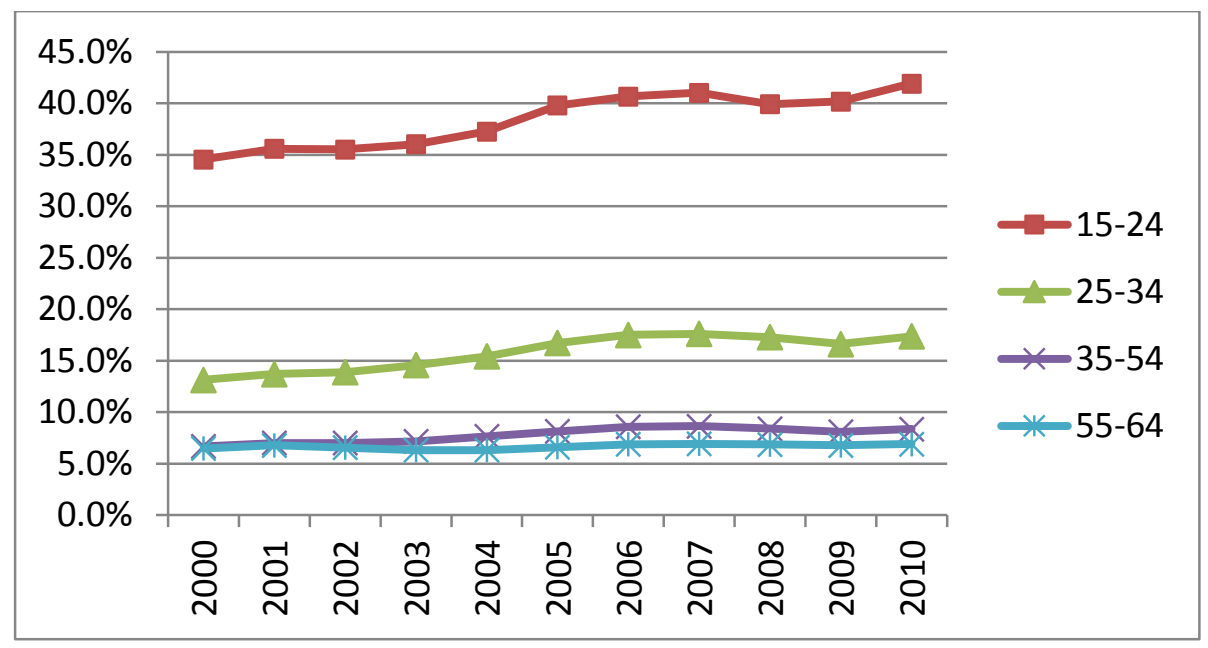

Figure 4. Share of temporary employment for EU-27 by detailed age grouping from 2000 to 2010(Source: Eurostat, LFS) 


\section{The scarring effects of unemployment and marginal employment}

Being out of work or only in a marginal type of employment can lead to long-term negative consequences, often referred to as 'scarring effects' (Arulampalam, 2001; Clark et al., 2001; Giesecke and Groß, 2003). These effects regard long-term levels of job satisfaction, happiness and health, but also more concrete conditions such as future unemployment and lower pay (Mroz and Savage, 2006). For the UK, Gregg and Tominey (2005) found that 20 years after a spell of youth unemployment, a significant wage penalty (15-20 percent) still existed. The penalty is higher when there has been repetitive exposure to unemployment during youth.

The scarring effect of temporary contracts is not clear. There is evidence to show that in some countries - such as the UK and Sweden - temporary contracts can be effective in helping people gain permanent positions (Booth et al., 2002; Korpi and Levin, 2001). In some cases the reason for the high proportion of temporary employment among young people is due to the fact that temporary contracts are used as a hiring tool (European Commission, 2010b; ROA, 2011). On the other hand evidence also shows that in other countries, marginal jobs are seen as a 'trap' where the chances of moving out are slim (Giesecke and Groß, 2003; Zijl and Van Leeuwen, 2005). D’Addio and Rosholm (2005), examining the European Household Panel, find that this is especially the case for very short contracts and for men. Guell and Petrongolo (2007) examined the conversion rate of temporary contracts into permanent ones on the Spanish labour market from 1987 to 2002, arriving at the conclusion that the conversion rate was less than 10 percent. In a recent OECD study Scarpetta et al. (2010) estimated that the probability of a (young) person finding a permanent job after having had a temporary contract the year before was slightly higher than 20 percent in Spain. Another study reporting general transition rates shows that between 2004 and 2007, the transition rate from flexible to permanent employment was 28 percent in Spain. At the time, this was higher than the Dutch transition rate (23 percent), whereas Sweden had a rate of almost 50 percent. In that same period the share of flexible work in Spain was however almost triple the rate of the Netherlands and Sweden (Muffels and Wilthagen, 2011). Low and decreasing transition rates into permanent employment may suggest that being in temporary work is a cohort effect rather than an age effect, meaning that younger generations may, in contrast to previous generations, be facing long-term labour market risks. Thus young generations are not 
selectively, but rather generally subject to certain risks and these risks are likely to play a role throughout their working lives.

\section{In-work poverty}

Young workers' insecurity is not restricted to employment. We find that this group is also much more likely to be in poverty than the rest of the population, due either to unemployment or low wages. For example, looking at the 2010 Eurostat averages for the EU-27, almost onethird of young individuals between the ages of 18 and 24 are at risk of poverty ( 29 percent). It seems that gainful employment does not decrease the poverty risk for young people to any great degree, with 16 percent of workers between the ages of 18 and 24 likely to be at risk of poverty despite having a job. This is on average 1.3 times higher than the risk for 25 to 49 year olds, and 1.5 times higher than for 50-64 year olds. Again the disparity is highest in Sweden, where young people are three times more likely (20.7 percent) to be at risk of poverty than workers in the 25-49 age range. Their in-work poverty rate is also the highest of the countries examined in this article. Employed Spanish young people in the 18-24 age range are also highly likely to be at risk of poverty (15.4 percent). However, we find that this likelihood is not very much higher than that of other age groups (13.7 percent for those between 25 and 49). The reason for this may be that young people in Spain are more likely to be living with their parents or older generations, thus allowing for intra-household transfers and making them less distinguishable as an age group. By contrast, young people in Sweden are more likely to leave home earlier and thus tend to live in separate households, increasing their likelihood of being included in the working poor group.

\section{Subjective insecurity}

Young people's insecurity in employment and income lead to subjective insecurities as well. Subjective insecurity concerning one's future may be higher for younger workers given their insecure status on the labour market and as recipients of social security benefits. Since most countries provide unemployment benefit based on a contributory insurance scheme, young workers are in many cases excluded from such benefits (see Section 3 for more details). We examined the subjective employment and income insecurity of European individuals using the 2008/2009 European Social Survey which covers the EU-27 excluding Austria, Italy, Ireland, Luxembourg and Lithuania, but including Norway and Switzerland. First, we see a great deal of income and employment insecurity throughout Europe, with about a quarter of all 
individuals perceiving income or employment insecurity. It seems that insecurity decreases with age, especially employment insecurity - i.e. the possibility of losing one's job and not being able to find another one relatively quickly (within four weeks). As regards income insecurity, it is those between 25 and 34, those likely to be parents of young children, who are more likely to perceive income insecurity than other age groups. Older (35-54) age groups also have rather high proportions of workers (29.6 percent) finding it difficult to live on current income, whereas the 55-64 and 65 plus age groups have fewer income worries. As regards employment insecurity, 33.6 percent of all individuals between the ages of 18 and 24 in the countries surveyed perceived their position on the labour market as being insecure in 2008/2009. This probability decreases with increasing age, and is significantly smaller for those over 65 . These patterns differ slightly from country to country. Looking at the countries in question, the Spanish pattern is not much different from the European average, although in general Spaniards are much more likely than the Dutch or Swedes to perceive both income and employment insecurity (30.5 percent perceiving income insecurity, 27.3 percent employment insecurity). In addition, a sense of income insecurity of those at an age to start up a family -25 to 34 - is much stronger (36.5 percent). This may also be associated with the fact that under-25s in Spain tend to live with their parents, though this is less the case for those over 25 . The fact that under-25s are more likely to live with their parents is reflected in their tendency towards employment insecurity (much higher than other age groups), but not income insecurity. By contrast the two forms of perceived insecurity are approximately the same for 25 to 34 year olds.

Young people in Sweden feel more insecure about their employment than in Spain, with more than 40 percent of Swedish young people in the 18-24 age range feeling that they are likely to lose their jobs and will be unable to find another one within a short period of time, whereas only about 19 percent feel that it is likely that they will not have sufficient income. This again may be due to private intra-household transfers and, in the case of Sweden, to public transfers. Again Sweden seems to be the country with the largest inter-generational disparities. In other words, although there are strong perceptions of insecurity amongst under-24s (and to a certain extent in the 25-34 age group), the rest of the population feels basically secure. Similarly, in the Netherlands, the young population between 18 and 24 feels more insecure than the general population, though this disparity is not as prominent as in Sweden. An interesting finding is 
that those between the ages of 25 and 34 are actually less insecure than other age groups, with the exception of pensioners.

Table 1. Income and employment insecurity of individuals across Europe, Spain, Netherlands and Sweden

\begin{tabular}{|l|l|l|l|l|l|l|l|l|}
\hline & \multicolumn{2}{l}{ EU24 } & \multicolumn{2}{l|}{ Spain } & \multicolumn{2}{l|}{ Netherlands } & \multicolumn{2}{l|}{ Sweden } \\
\hline & income & employment & income & employment & income & employment & income & employment \\
\hline $18-24$ & 27.8 & 33.6 & 27.8 & 37.0 & 15.6 & 14.2 & 18.6 & 41.8 \\
\hline $25-34$ & 32.6 & 30.5 & 36.5 & 38.1 & 8.0 & 9.3 & 13.5 & 18.9 \\
\hline $35-54$ & 29.6 & 24.7 & 33.0 & 31.5 & 10.2 & 11.4 & 7.5 & 13.7 \\
\hline $55-64$ & 25.6 & 18.6 & 25.9 & 17.4 & 9.2 & 12.2 & 5.7 & 11.9 \\
\hline $65+$ & 24.5 & 5.6 & 25.7 & 2.2 & 5.3 & 1.0 & 8.5 & 0.9 \\
\hline total & 24.1 & 28.2 & 30.5 & 27.3 & 9.6 & 10.5 & 9.8 & 17.5 \\
\hline
\end{tabular}

Source: European Social Survey 2008/2009.(EU24= EU 27 excluding Austria, Italy, Ireland, Luxembourg, Lithuania, including Norway and Switzerland).

\section{Comparing policy responses in the three countries}

Data show that young workers are often in insecure jobs, as witnessed by higher unemployment rates and a higher likelihood of having temporary jobs. As a result, young people experience employment and income insecurity. Such problems are not limited to those fresh out of education, but also affect people who have been in the labour market for a while i.e. 25 to 34 year olds. One would therefore expect national policies to address the negative consequences of long-term temporary employment and that the economic crisis would have acted as an incentive to implement appropriate employment and social policies. This section shows that such initiatives were not always forthcoming. We illustrate this by describing the policies of three countries (Spain, the Netherlands and Sweden), each representing a different regime type (Esping-Andersen, 1990). In addition the three countries are diverse in their performance in terms of youth unemployment and sustainable jobs. The analysis regards three policy categories: (initial) education and training, labour market participation and social security provisions.

\section{3-1. In-school training and education policies}

One of the most frequently used policies for tackling youth labour market problems is increasing youth participation in education and training. As this mainly involves initial 
vocational education and training (IVET), the measures target young people in their lower 20s. The rationale behind such policies is that better educated young people are less likely to become unemployed and have a higher chance of moving from temporary to permanent employment (Scarpetta et al., 2010). This focus on education is also present in our three casestudy countries, where a number of supply-side policies introduced after the crisis encourage young workers to engage in education and training.

In Spain, three different measures were introduced to tackle early school leaving, including one to prevent early school leaving by providing additional lessons and support programmes for students with special education needs and another one motivating early school leavers to return to education (González Gago and del Río Hernández, 2010). The latter provides the opportunity of enrolling in training courses to gain vocational skills, thus entitling participants to a degree equivalent to secondary education. This degree then allows students to enrol in further VET courses. A third measure was designed to enhance the employability of experienced workers without formal training certificates, through recognizing skills acquired through work experience.

The Dutch government similarly actively supports young people's training and education. In September 2009 an 'Action plan to fight youth unemployment' was introduced. The main programmes aim at keeping young people in school through stimulating those with bleak labour market perspectives to think about their future, providing a combination of theoretical and practical training, and creating better support systems for the most vulnerable groups of young people. For example this was done by offering young workers a combination of education, care, general support and support in moving from school to the labour market (Bekker, 2010). Stakeholders such as schools, (local) administrations and the public employment service (PES) also take a more preventative approach to early school leaving, for instance by making transitions between school types and levels easier and by offering career guidance and enhancing on-the-job learning (Research voor Beleid, 2011).

In Scandinavia as well, education is largely seen as the best way of fighting youth unemployment (Preisler, 2010). Sweden introduced several educational and training measures in the aftermath of the crisis, most of which focus on (temporarily) enhancing the number of places in education and training and training opportunities at various levels of education, such as post-secondary and advanced VET, universities, polytechnics, and work placement and 
trainee schemes (Anxo, 2010). Another measure to encourage people to apply for secondary adult VET involved a temporary increase in opportunities for post-secondary student aid for all unemployed people over the age of 25 . Within the framework of a 'Job Guarantee', school drop-outs are given the opportunity of completing their studies. An upper secondary pilot apprenticeship programme was also introduced in close collaboration with the social partners and the school authorities in 2008. Moreover, a permanent apprenticeship programme became part of the curriculum in 2011 better to prepare students for working life. The quality of vocational training will be further improved through closer collaboration between high school authorities and local actors. The Swedish government is also promoting youth entrepreneurship by giving education a key role in its encouragement.

\section{3-2. Measures taken to promote youth employment}

Along with focusing on more education, national governments have introduced measures encouraging employers to hire young workers. These include changes in employment contracts, government subsidies and reductions in employers' social security contributions, which apply to young people up to the age of 25 in Sweden, 27 in the Netherlands and 30 in Spain. Spain is the only country devoting attention to the negative consequences of consecutive fixed-term employment contracts, enacting legislation to (albeit unsuccessfully) encourage transitions into more stable jobs (González Gago and del Río Hernández, 2010; Wölfl and Mora-Sanguinetti, 2011). By contrast, the Netherlands and Sweden have paid much less attention to problems related to temporary and part-time employment (Bekker, 2010; Anxo, 2010). This might be associated with the very high and persistent incidence of temporary employment in Spain, leading the country to experience the most pressure to change. Moreover, Spain has relatively flexible job protection regulations regarding temporary contracts, while upholding strictly regulated permanent contracts (Eichhorst et al., 2010). Most temporarily employed workers are in this position involuntarily and have very short-term contracts lasting fewer than six months. Such contracts were the main vehicle for carrying the 'burden of adaptation' during the 2008-2010 recession (Eichhorst et al., 2010: 29).

The biggest reform made to the Spanish market to tackle the problem of high youth unemployment involved the 1997 introduction of a special employment contract to stimulate the recruitment of young workers (González Gago and del Río Hernández, 2010). Through this contract, employers pay reduced social security contributions and lower redundancy costs 
for disadvantaged workers including young workers. The reform of September $2010^{2}$ introduced further reductions in social security contributions for employers hiring workers aged 16-30. Firms that hired young and unqualified unemployed on permanent contracts before 31 December 2011 received hiring subsidies in the form of social security rebates for a maximum period of three years. Additional wage subsidies were introduced for hiring people on training contracts signed before 31 December 2011 (Wölfl and Mora-Sanguinetti, 2011: 10). However, these measures have not prevented unemployment and the incidence of temporary employment from rising further, probably due to the lack of skills of those laid-off (Eichhorst et al., 2010: 30). The jobs created in the pre-crisis economic boom and subsequently lost were predominantly low-skilled and low-productivity jobs in construction. Whereas Spain acknowledges the problems related to fixed-term contracts, the Netherlands conversely temporarily increased the opportunities for employers to keep young people in fixed-term work for longer. This shows that the Dutch government does not necessarily acknowledge temporary contracts as being a problematic feature of youth employment. It extended the legal duration of temporary contracts for younger workers, meaning that rather than keeping the limit to three consecutive temporary contracts within a maximum of 36 months, employers were temporarily allowed to offer four consecutive fixed-term contracts for a maximum of 48 months (Bekker, 2010). This measure was aimed at preventing employers from making younger workers with a temporary contract redundant, but after negative assessments the measure was abolished in 2012.

Not much has been done in the three countries in terms of job creation. The only measures taken involved promoting self-employment as a way of getting young workers into work. Other concrete demand-side measures consist of providing subsidies for employers and cutting the costs of hiring young workers, such as arrangements for employers to pay lower social security contributions for their young personnel. One Dutch measure cut the wage costs associated with hiring young workers through a tax measure exempting employers from paying premiums for workers under the age of 23 with a low-income job (i.e. less than half of the minimum wage). The measure was effective in 2010 and 2011, but was abolished in 2012 . Swedish programmes for young labour market entrants mostly focus on the group aged up to 25 and often consist of tax reductions for employers (Anxo, 2010). One reform aimed at

\footnotetext{
${ }^{2}$ Law 35/2010 of 17 September 2010, mainly based on the Royal Decree-Law 10/2010 of 16 June 2010.
} 
decreasing employers' payroll taxes for employing young people (up to age 25) started with an 8 percent reduction of wage costs in 2007, gradually increasing the reduction to 13 percent in 2009 (Kullander and Johansson, 2011). Employment promotion measures also involved reductions of social security contributions for young workers under the age of 26. In 2009, employers' social security contributions for young people were lowered from 21.3 percent to 15.5 percent (Bennmarker et al., 2011). Moreover, young people aged 20-25 who have been unemployed for more than six months become eligible for a 'New Start Job' (Nystartsjobb). This provides compensation for employers equivalent to an employer's normal social security contribution. Together, the reductions in social security contributions amount to about 40-50 percent of the wage costs associated with hiring a young person in a new start job (Anxo, 2010).

\section{3-3. Active labour market policy and social security}

Given young people's income and employment insecurity, it is interesting to explore their eligibility to social security benefits and assistance in finding a job. In all three countries, the unemployment benefit system is mainly based on the period worked prior to becoming unemployed and on the wage previously earned. This system prevents young people with little or no work experience from benefiting from unemployment benefits due to their insufficient contribution record. This is also the case for flex workers moving in and out of employment. Sweden is the only country of the three to have reformed its unemployment benefit system to tackle the difficulties experienced by young people in accessing benefits, temporarily reducing contribution and length-of-employment requirements in response to the crisis (EEO, 2011). Swedish unemployment benefits are normally based on the last 12 months' earnings and require a person to have worked for at least six months and at least 80 hours in every calendar month, i.e. 480 hours during six consecutive calendar months (Anxo, 2010). During 2009 , access requirements for unemployment benefits were lowered from one year to six months and the requirement for having to work in order to join a fund was abolished, making it easier for the unemployed and students to join an unemployment insurance fund. In the case of Spain, the exclusion of young workers from the unemployment benefit system is a major problem, especially with almost half of this population currently unemployed and the figure expected to rise. 
Activation policies for young workers through guidance, coaching and job matching services have also been introduced, although they target mainly the under-25s. In the aftermath of the economic crisis, the Swedish government for instance instructed the PES to expand its matching services, targeting not only older workers, but also the young. Alongside such early and individual support through coaching, a Job Guarantee scheme (jobbgaranti för ungdomar) for young people was introduced in 2009, aimed at helping young people find a job more rapidly or enrol in the regular education system (Anxo, 2010). The Job Guarantee is restricted to unemployed under-25s who have been registered with the PES continuously for three months. Its purpose is to offer special measures at an early stage such as an intensified analysis of the person's situation and abilities, study and career guidance or jobseeker activities with coaching or work experience and training (Swedish PES, 2009). In 2010, further measures within the framework of the Job Guarantee were introduced, including new activation measures, support for starting up a business, and vocational rehabilitation, and the option to participate part-time in the guarantee in order to combine it with studies.

In Spain, activating policies have been similarly developed to tackle youth unemployment (González Gago and del Río Hernández, 2010). The first measure included training and guidance activities managed by the regional PES. Royal Decree 1/2011 introduced a temporary scheme specifically targeting certain vulnerable groups: young people, the longterm unemployed aged over 45 , and low-skilled workers from the construction sector as well as those hit most by the economic situation. It aims to promote transitions into stable employment and to retrain the unemployed, providing individual pathways with particular types of training. Participation is mandatory to receive unemployment benefit payments (González Gago and Castellanos Serrano, 2011).

The Netherlands introduced the 'Investment in Youth Act' (IYA; Wet Investeren in Jongeren) to activate young workers. This fundamentally changed eligibility to social assistance. In force between October 2009 and December 2011, this Act stopped providing people aged 1827 with an automatic entitlement to social assistance. Instead, young people were to be offered work, education or a combination of the two. Young people refusing to accept such an offer were denied benefits. If they accepted a job, they received a salary from their employer. If accepting education, they were given, if deemed necessary, an income equivalent to social assistance benefits. Though there has not been much debate on the IYA, questions have been raised as to whether young workers should be denied benefits solely on account of their age. 
As of 1 January 2012, the IYA will be integrated into a new Act called the Work Capability Act (Wet Werken naar Vermogen), set to come into force in 2013. This new Act contains specific regulations for under-27s and is expected further to reduce their access to social assistance (Ministry of Social Affairs and Employment, 2011). In the first month after a firsttime application for benefits, a young person is not given any financial assistance, but is instead sent home to engage in job-searching activities or to apply for education. After this month, the young person may return and apply for social assistance. Moreover, the new Act stipulates that when a young person has the possibility of returning to state-supported education, he or she should do so. In such cases, he or she is denied socal security benefits.

\section{Youth policies within the Europe 2020 strategy}

Policies tackling youth issues have also been developed at EU level. Part of the Europe 2020 strategy is the Youth on the Move flagship initiative which aims at 'unleashing the potential' of young people through quality education and training, successful labour market integration and increased mobility. This initiative is biased towards education, only focusing on the labour market position of young people to a lesser extent, with three of its four main lines of action addressing educational issues. First, the lifelong learning initiatives aim at reducing early school leaving to 10 percent, acknowledging non-formal learning, and promoting apprenticeship-type vocational training and high quality traineeships as workplace learning experiences. The second line of action aims to increase participation in higher education with the ultimate aim of 40 percent of 30-34 year olds completing higher education. This includes reforming and modernizing higher education, benchmarking university performance, promoting the attractiveness of European higher education and fostering academic cooperation and exchanges. The third line of action includes support for studying and working abroad, while the fourth one addresses the improvement of the employment situation of young people. Here, the European Commission also addresses problems concerning youth unemployment and labour market segmentation (European Commission, 2010a). Although the hiring of young workers via temporary contracts is on the one hand still viewed as a way for companies to test workers' skills and productivity, the Commission also acknowledges that all too often temporary contracts are used as a cheaper alternative to permanent ones. For young individuals this may mean experiencing a sequence of temporary jobs alternating with 
unemployment or periods of inactivity, few chances to move to open-ended contracts, insufficient contributions to pension funds, lower income and a higher probability of unemployment (European Commission, 2010a: 13).

However, as time progresses and the effects of the crisis start to affect young people even more, job quality and a sustainable labour market entrance have gained in importance in EU debates, with greater attention being given to demand-side approaches. In January 2012, Barroso urgently addressed what he called the unacceptable reality of massive youth unemployment (Europa, 2012). He asked the European Council to set up 'action teams', consisting of the Commission, national authorities and social partners in eight countries with very high youth unemployment rates (Spain, Greece, Slovakia, Lithuania, Italy, Portugal, Latvia and Ireland). In the same month the European Council agreed to stimulate youth employment, also emphasizing inclusion into quality jobs. This agreement is likely to increase pressure at national level to step up '... efforts to promote young people's first work experience and their participation in the labour market: the objective should be that, within a few months of leaving school, young people receive a good quality offer of employment, continued education, an apprenticeship, or a traineeship' (European Council, 2012).

Moreover, EU funding such as the European Social Fund will be used to support initiatives to reduce youth unemployment. Finally, the National Reform Programmes have to include a section with a detailed job creation plan.

The EU's Youth on the Move initiative highlights some of the risks inherent in having many consecutive temporary jobs: lower income, a higher probability of unemployment and missing pension contributions. Even so, the focus of the overarching Europe 2020 strategy on increasing labour participation to 75 percent creates the risk of Member States focusing first and foremost on getting people into any job, regardless of its quality. This risk is increased by high and still rising (youth) unemployment rates. Recent EU activities partly addressing the demand side of the unemployment problem and additionally emphasizing a good quality offer of employment have the potential to counteract the previous supply-side emphasis on more schooling and activation into any kind of job. How this influences future activities of Member States remains to be seen. 


\section{Outlook: limitation of policy approaches}

This article illustrates that the changes in the labour markets have created a new generation gap. Young people are now exposed to higher risks of unemployment after completing their training and education. Even when finding jobs, these are often temporary and low-paid, with no guarantee of a transition to better jobs in the future. In addition, it seems that the recession is hitting younger generations much harder than other age groups.

This systematic increase in both employment and income insecurity is set to have both shortand long-term effects on young people and has consequences not only for individuals but also for society at large. In the short term, young people are more likely to perceive income and employment insecurity. If these perceptions continue for extended periods of time, they are likely to have an effect on health and well-being (Ashford et al., 1989; De Witte, 1999; Ferrie, 2001). Moreover, young people experiencing insecurity are less likely to start a family, thereby affecting fertility rates (Bernardi et al., 2008; Blossfeld, 2005). In our view, existing tools are insufficient for analysing the effects this is having and for combating any possible resultant problems. New social policies and additional labour legislation, providing meaningful protection of young people in the labour market, are needed. One feature of both the Europe 2020 programme and the majority of policies in the three Member States explored is the rather paternalistic approach to tackling the employability deficits of young people, as witnessed by the heightened emphasis put on the supply side of labour market policies and the lack of true stable security provisions. Encouraging more education and training obviously makes sense, especially when targeting people who left school early. Indeed, there is evidence that people with low- and medium-level qualifications have been hit harder by the recent crisis (Cedefop, 2011; European Commission, 2010c; Scarpetta et al., 2010). However, there is a limit to emphasizing education as the one and only solution to labour market problems. What is also needed is a macroeconomic approach stimulating labour demand (Krugman, 2011). Although education seems to give young people the best competitive edge when competing against their peers, 'educational inflation' may result in higher unemployment rates of well-qualified young people. Furthermore, education return on investment will vary depending on national policies and regime context (Iannelli and Raffe, 2007; Trostel et al., 2002). Although the importance of education is constantly highlighted in all political rhetoric, government austerity measures in many countries have led to cuts in higher education 
expenditure. Thus, more education and supply-side policies cannot be the only route to sustainable labour market inclusion.

Another aspect that needs to be dealt with is the exclusion of young workers from social security benefits. In our analysis of the three country examples, Sweden is the only country addressing the precariousness of young people through easier access to unemployment benefits, whereas the Dutch social assistance is becoming increasingly difficult for young people to access. This lack of focus continues at EU level, with the Europe 2020 ignoring social security provisions for young people. Given the level of unemployment of this age group and the concomitant level of perceived income insecurity, the issue of social security inclusion is one of urgency, with implications for the sustainability of EU and national strategies.

Given that the insecurity discussed here is set to be a lasting phenomenon with perhaps even longer lasting consequences, also for slightly older young people, it seems increasingly important to hear young people's voices. Unfortunately, despite the recent youth demonstrations and riots, most young people are not yet politically as active as other agerelated interest groups. Just as older workers have taken to the streets to fight pension cuts, younger workers similarly need to take action to tackle some of the important issues affecting their futures, not in order to fuel a conflict between generations, but rather to make sure that younger generations' needs are addressed. Young people need secure employment and sufficient means to embark on an independent life and contribute to society and the economy.

The role of unions in this respect is paramount. First, the long-term prospects for trade union survival are to a great extent dependent on younger workers entering the labour market. Without them the sustainability of union power is under threat. Secondly, by also prioritizing some of the issues young workers are facing, unions can effectively tackle issues affecting all workers. This means also paying attention to slightly older young people. The problems affecting young workers do not automatically disappear once these workers reach a certain age. Only by providing young people with a sustainable future, can the future of older generation be secured. 


\section{Funding}

This research received no specific grant from any funding agency in the public, commercial, or not-for-profit sectors.

\section{References}

Anxo D (2010) EEO Review: Youth Employment Measures, 2010 Sweden. European Employment Observatory.

Arulampalam W (2001) Is Unemployment Really Scarring? Effects of Unemployment Experiences on Wages. Economic Journal 111(475): F585-F606.

Ashford SJ, Lee C and Bobko P (1989) Content, causes, and consequences of job insecurity: A theory-based measure and substantive test. Academy of Management Journal 32(4): 803-829.

Bekker S (2010) EEO Review: Youth Employment Measures, 2010 the Netherlands. European Employment Observatory.

Bennmarker H, Calmfors L, Council SFP et al. (2011) Wage Formation and the Swedish Labour Market Reforms 2007-2009. Studier i Finanspolitik 2011/1.

Bernardi L, Klärner A and Von Der Lippe H (2008) Job Insecurity and the Timing of Parenthood: A Comparison between Eastern and Western Germany. European Journal of Population/Revue Européenne de Démographie 24(3): 287-313.

Blossfeld HP (2005) Globalization, uncertainty and youth in society. Psychology Press.

Booth AL, Francesconi M and Frank J (2002) Temporary jobs: stepping stones or dead ends? The Economic Journal 112(480): F189-F213.

Cedefop (2011) What does it take to become employable? Guiding young people into the labour market. Background Paper for European Parliament joint seminar on youth employment, 30 June 2011.

Clark A, Georgellis Y and Sanfey P (2001) Scarring: The Psychological Impact of Past Unemployment. Economica 68(270): 221-241.

D'Addio AC and Rosholm M (2005) Exits from temporary jobs in Europe: A competing risks analysis. Labour Economics 12(4): 449-468.

De Witte H (1999) Job insecurity and psychological well-being: Review of the literature and exploration of some unresolved issues. European Journal of Work and Organizational Psychology 8(2): 155-177. 
EEO (European Employment Observatory) (2011) European Employment Observatory Review. Adapting unemployment benefit systems to the economic cycle. European Commission.

Eichhorst W, Escudero V, Marx P et al. (2010) The Impact of the Crisis on Employment and the Role of Labour Market Institutions. IZA Discussion Papers No. 5320. Institute for the Study of Labor (IZA).

Esping-Andersen G (1990) The Three Worlds of Welfare Capitalism. Princeton: Princeton University Press.

Europa (2012) Statement by President Barroso following an informal meeting with the Social Partners, MEMO/12/33, 23 January 2012, Brussels.

European Commission (2010a) Youth on the Move. An initiative to unleash the potential of young people to achieve smart, sustainable and inclusive growth in the European Union. Communication from the Commission to the European Parliament, the Council, the Economic and Social Committee and the Committee of the Regions, $\operatorname{COM}(2010) 477$ final, 15 September 2010, Brussels.

European Commission (2010b) Employment in Europe 2010. Luxembourg: European Commission.

European Commission (2010c) Employment in Europe 2010. Luxembourg: Publications Office of the European Union.

European Council (2012) Towards growth-friendly consolidation and job-friendly growth. Brussels 30 January 2012.

European Foundation for the Improvement of Living and Working Conditions (2011) Foundation Findings: Youth and Work. Dublin: European Foundation for the Improvement of Living and Working Conditions.

Ferrie JE (2001) Is job insecurity harmful to health? Journal of the Royal Society of Medicine 94(2): 71-76.

Giesecke J and Groß M (2003) Temporary Employment: Chance or Risk? European Sociological Review 19(2): 161-177.

González Gago E and Castellanos Serrano C (2011) EEO Review: Adapting unemployment benefit systems to the economic cycle, 2011 Spain. European Employment Observatory.

González Gago E and del Río Hernández F (2010) EEO Review: Youth Employment Measures, 2010 Spain. European Employment Observatory. 
Gregg P and Tominey E (2005) The wage scar from male youth unemployment. Labour Economics 12(4): 487-509.

Guell M and Petrongolo B (2007) How binding are legal limits? Transitions from temporary to permanent work in Spain. Labour Economics 14(2): 153-183.

Holzer HJ (1987) Informal job search and black youth unemployment. The American Economic Review 77(3): 446-452.

Ihlanfeldt KR and Sjoquist DL (1990) Job accessibility and racial differences in youth employment rates. The American Economic Review 80(1): 267-276.

ILO (2011) Global Employment Trends for Youth: 2011 Update. Geneva: International Labour Office.

Korpi T and Levin H (2001) Precarious Footing: Temporary Employment as a Stepping Stone out of Unemployment in Sweden. Work, Employment \& Society 15(1): 127-148.

Kullander, M and Johansson E (2011) Sweden: EIRO CAR on Helping young workers during the crisis: contributions by social partners and public authorities. EIROnline, 1 August 2011.

Krugman P (2011) Degrees and Dollars. New York Times, 6 March.

Ministry of Social Affairs and Employment (2011) Memorie van toelichting bij het wetsvoorstel tot wijziging WWB en WIJ. 17.06.2011.

Mroz TA and Savage TH (2006) The long-term effects of youth unemployment. Journal of Human Resources 41(2): 259-293.

Muffels R and Wilthagen T (2011) Flexwerk en werkzekerheid in tijden van crisis. Economisch Statistische Berichten 96(4602), 21 January 2011.

Preisler M (2010) Early, active measures to fight youth unemployment. Nordic Labour Journal, October 2010

Research voor Beleid (2011) Samen in actie. Evaluatie Actieplan Jeugdwerkloosheid. Zoetermeer. Research voor Beleid.

ROA (Research Centre for Education and the Labour Market) (2011) Why do recent graduates enter into flexible jobs? Research memorandum 2011/10.

Scarpetta S, Sonnet A and Manfredi T (2010) Rising Youth Unemployment During The Crisis: How to Prevent Negative Long-term Consequences on a Generation? OECD Social, Employment and Migration Papers No.106. Paris: OECD.

Swedish PES (2009) An Introduction to Arbetsförmedlingen, the Swedish Public Employment Service. Stockholm: Swedish Public Employment Service. 
Wölfl A and Mora-Sanguinetti JS (2011) Reforming the Labour Market in Spain. OECD Economics Department Working Papers No. 845. OECD Publishing.

Zijl M and Van Leeuwen M (2005) Temporary Jobs, Intermediate Positions or Jumping Boards; Searching for the Stepping-Stone Effect of Temporary Employment. SEO Discussion Paper No. 38. 